\title{
Study on the strategy of improving urban resilience from the perspective of sponge city construction
}

\author{
Fujun XIA, Shanghai Tongji Urban Planning \& Design Institute Co.Itd, China
}

\begin{abstract}
Urban resilience refers to the ability of a city to cope with disasters and recover its basic functions rapidly. Urban transportation, urban infrastructure, urban public policy-making and other aspects can improve the resilience of the city. At present, the urban water environment in China is still deteriorating, and the rainstorm and waterlogging disasters are still frequent. Therefore, the author chooses the sponge city construction to study the strategies to improve the urban resilience.

The author chooses two aspects of urban storm and waterlogging disaster control and surface runoff, which are closely related to the improvement of urban resilience, as the main research objects, selects specific evaluation indexes and proposes calculation functions, and adopts multiple research methods such as typical case study, spatial model simulation quantitative analysis, statistical analysis and empirical research, through arc GIS analysis, PCSWMM modeling and grasshopper data-based research By means of design and horizontal comparative study of three practical cases, this paper makes a qualitative and quantitative study on the strategy of sponge city construction performance to improve the city's resilience, and the quantitative research is mainly used.

There are two main achievements in this study: a set of quantitative research methods to improve the resilience of sponge city construction is preliminarily explored through the application of the evaluation model; some strategies to improve the resilience of sponge city construction are proposed.
\end{abstract}

\section{Keywords}

Sponge City, Quantitative assessment, Urban resilience, Model simulation

\section{Heading}

Most cities in China today face a variety of water crises: water shortage, water pollution, urban rainstorms, increased surface runoff, falling groundwater levels, shrinking and even loss of aquatic habitats (Wang Hao, 2011). These problems which are systematic and comprehensive are not caused by a single water sector or a functional department. If we want to solve these "water problems," we need a more systematic and integrated solution. The "sponge city" theory is based on the basic characteristics of China's water conditions and the "water problems" it faces. In the construction of the sponge city, what can be done in the planning field and what kind of contribution can be made is still unclear.On July 10, 2015, the <Measures for the Evaluation and Assessment of Sponge City Construction Performance (Trial)> issued by the Ministry of Housing and Urban-Rural Development of China was also mainly to evaluate the performance of China's sponge city construction. Once the city is built, it will become a fact. After-thefact evaluation can only evaluate the quality of the previous plan, but there is no way to change the existing facts. Therefore, it is particularly important to make an effective and reliable assessment of different planning schemes before the construction of the sponge city, and to select better schemes and further optimize them. 


\section{Sponge City Construction Performance Evaluation Method and Simulation}

\subsection{Definition of Sponge City Construction Performance Concept}

The performance evaluation content of this paper is mainly in the urban planning land use planning, which belongs to the program evaluation before the implementation of the plan. The selected indicators are the urban storm flood control and surface runoff. The definition of the sponge city construction performance concept is based on the above considerations, and the concept can be defined as: land use planning to prevent floods in urban storms and to control the comprehensive ability of surface runoff.

\subsection{Sponge City Construction Performance Evaluation Function}

The performance evaluation of sponge city construction includes two major indicators: urban storm flood control and surface runoff, and urban storm flood control includes whether there is heavy rain or not, and the total accumulated water time and total water volume in the flood water in the flood season. According to the item index, this study uses AHP(Analytic hierarchy process) to conduct qualitative and quantitative evaluation and decision-making on the evaluation of the final sponge city construction performance. The sponge city construction performance hierarchy is shown in Figure 1.

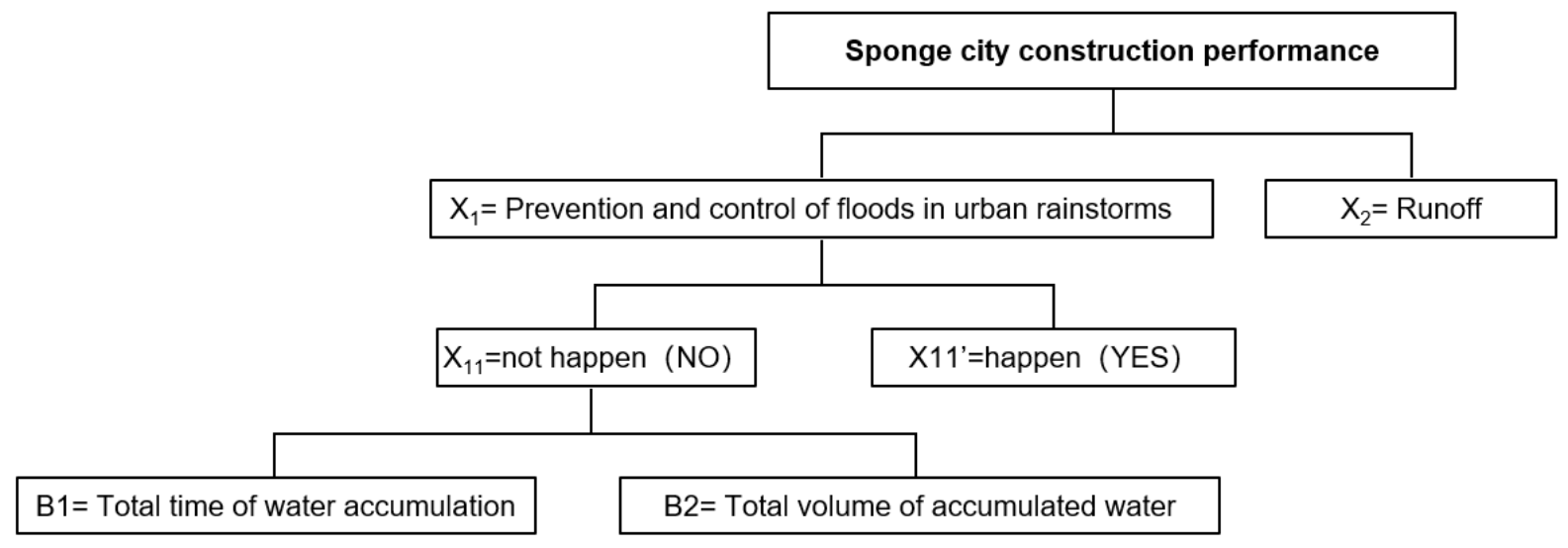

Figure 1. Sponge City Construction Performance Hierarchy

Source: author paint

\subsection{Experimental Platform and Tools (PCSWMM software)}

SWMM developed by EPA is a dynamic precipitation runoff simulation model, which is mainly used to simulate the time and long-term water and water quality simulation of a certain city. The evaluation software PCSWMM used in this paper is the commercialized software developed by the Canadian Institute of electronic water Resources based on the SWMM model.

\subsection{Multi Scheme Model Simulation Method and Process of Sponge City Construction Performance}

Through model simulation, a set of effective methods to observe and compare the multi scheme of land planning is set up in the early stage of planning, and the difference of the construction performance of the different land use scheme can be reflected as true as possible so as to select the better scheme and optimize it.

\subsubsection{Establishing a multi-scheme model}

The establishment of a multi-program model first requires the introduction of basic data, including geological data, climate data (including temperature, evaporation, wind speed, etc.), hydrological data 
(including rainfall, evaporation, etc.), terrain data and other data. The second is to introduce different land use planning schemes into the model.

\subsubsection{Model simulation output data analysis}

The total surface runoff of each land use plan, the total time of flood disasters and the total amount of floods were compared, and the performance index of sponge city construction was obtained. Then, the sponge city construction performance evaluation function was used to compare and score each plan, and better plan was selected and optimized.
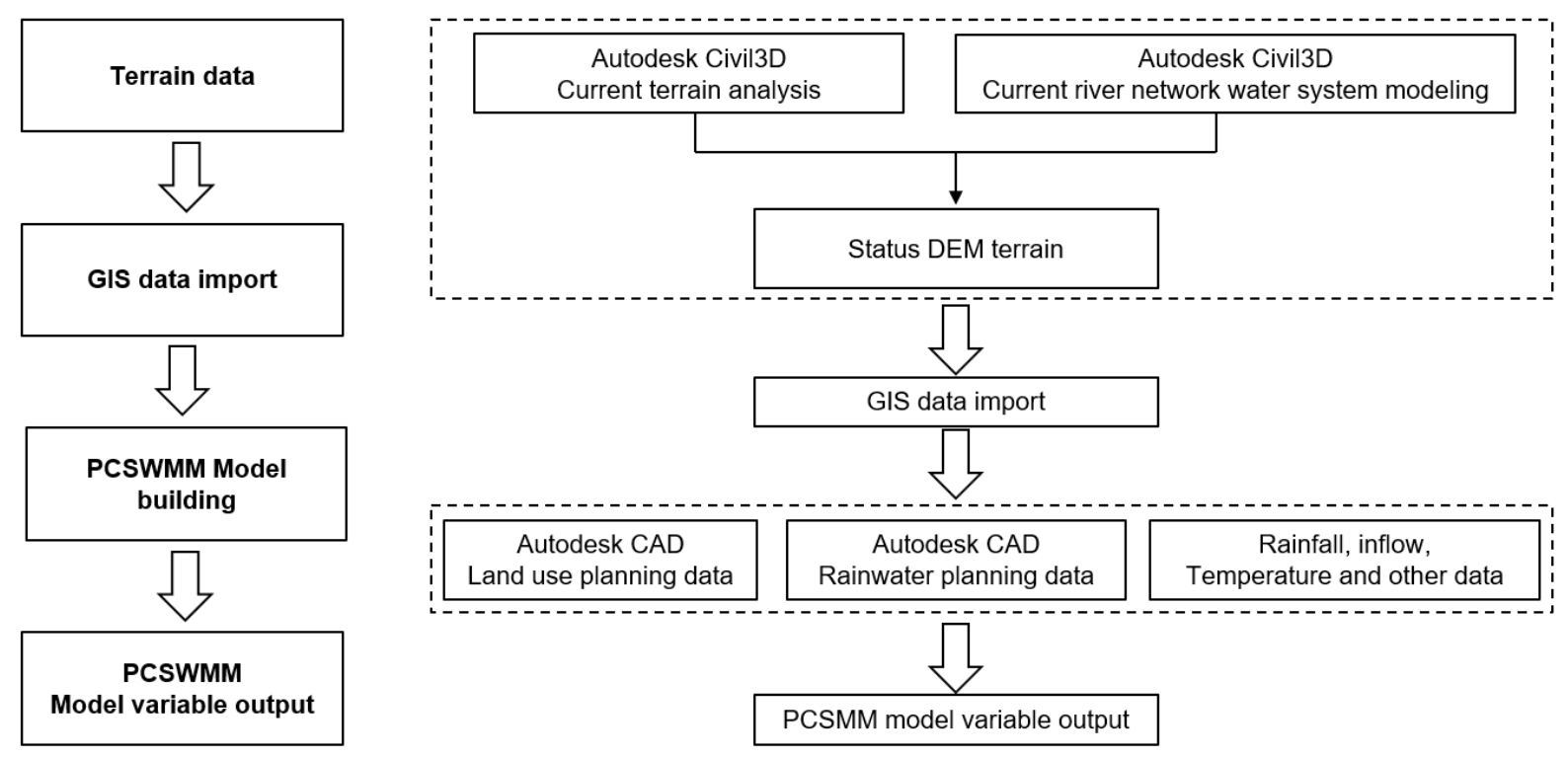

Figure 2. Schematic diagram of the modeling process

Source: author paint

\section{Empirical Study on Performance Simulation and Evaluation of Sponge City Construction}

\subsection{Case Overview}

Wuzhou is located in the eastern part of Guangxi China, located in the middle reaches of the Pearl River Basin, with an area of 12585 square kilometers and a population of 3.4 million. The research object of this paper is located in the south side of Cangwu County, Wuzhou City. The specific location is shown in Figure 3. It has been invaded by heavy rain and flood for many years.

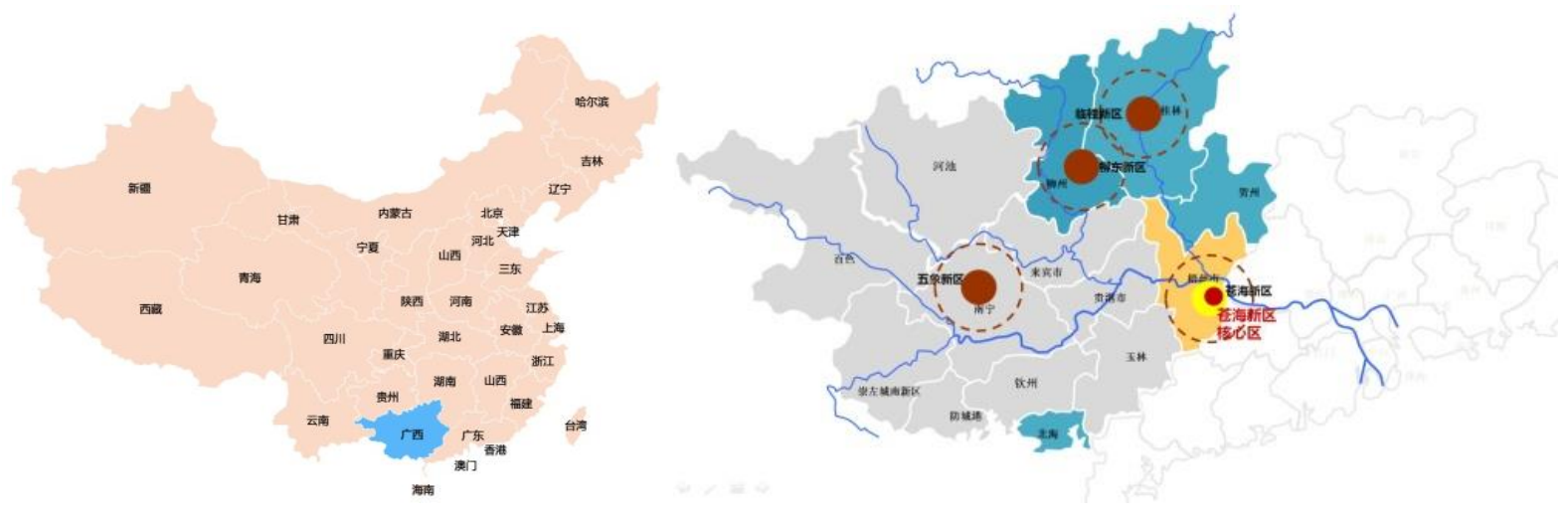




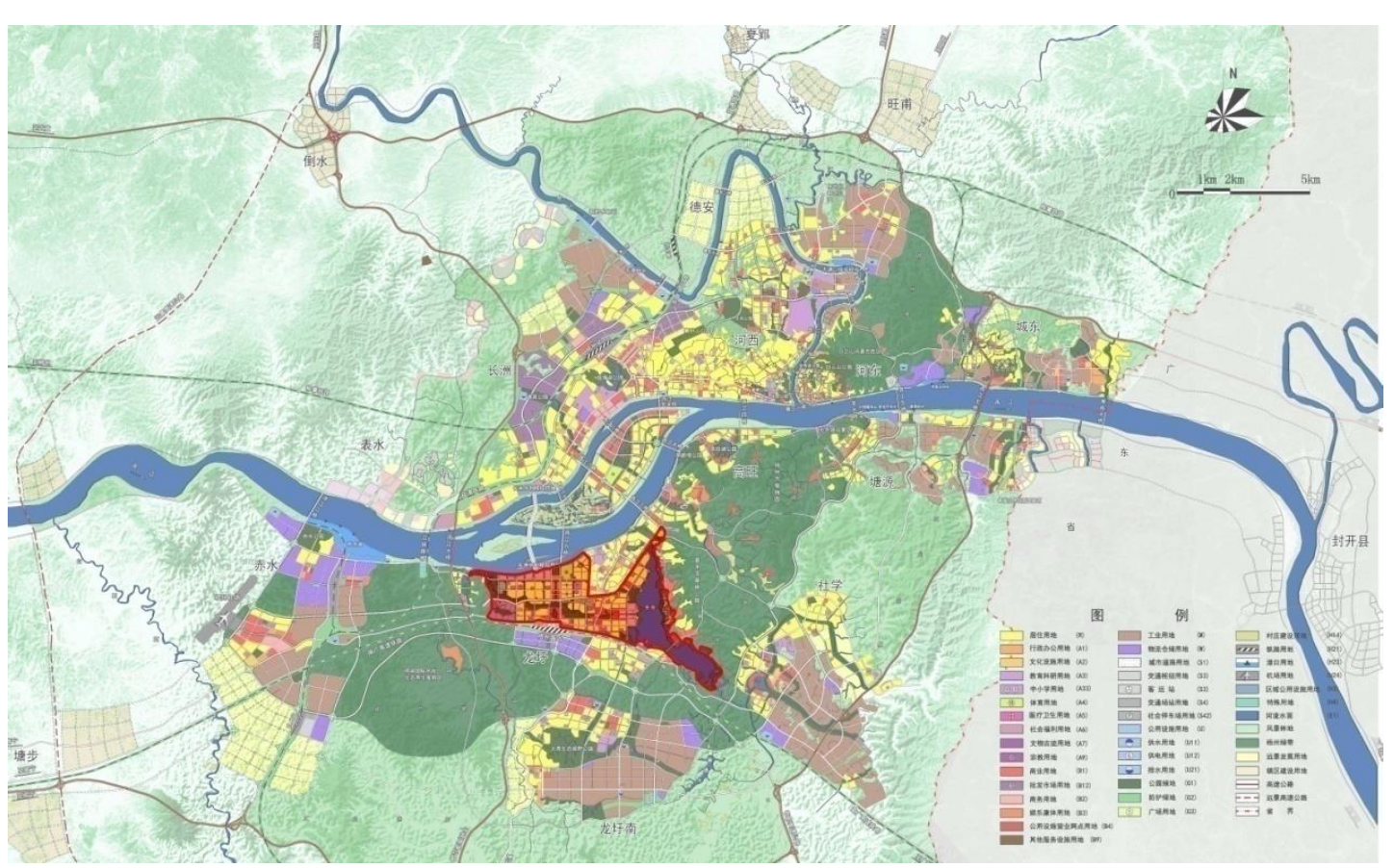

Figure 3. Location map of the study area

Source: author paint

The research in this paper is mainly aimed at the prevention and control of urban flood disasters and the surface runoff in different rainfall day study areas, especially the heavy rain days, and the evaluation of the performance of sponge city construction in different land use planning schemes. Therefore, the historical rainfall data within the study area is especially important for this study. According to the statistics of rainfall from 1959 to 2010 in the study area (the data is not classified because of the confidentiality of the data), the statistics are shown in Figure 4.
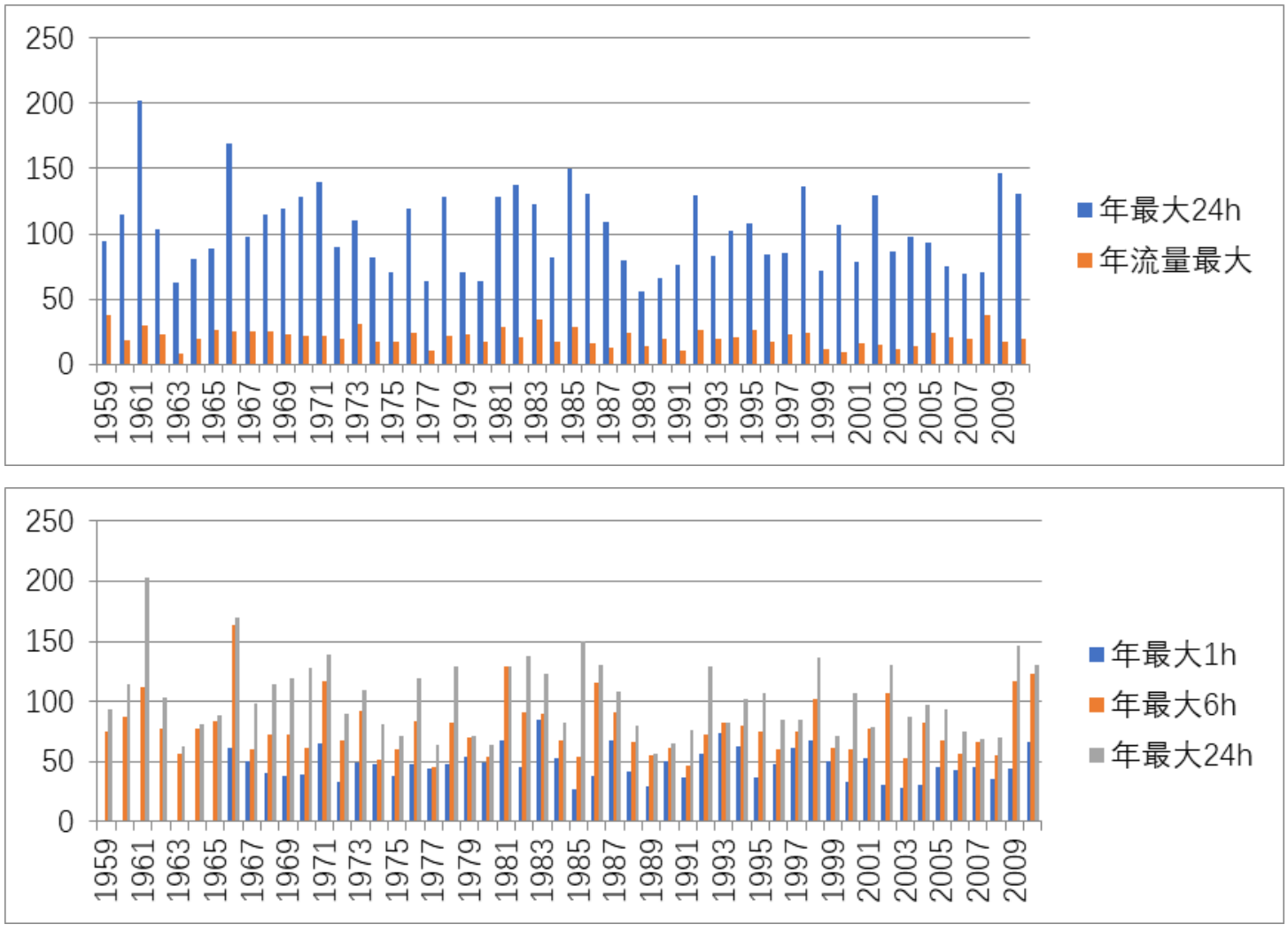

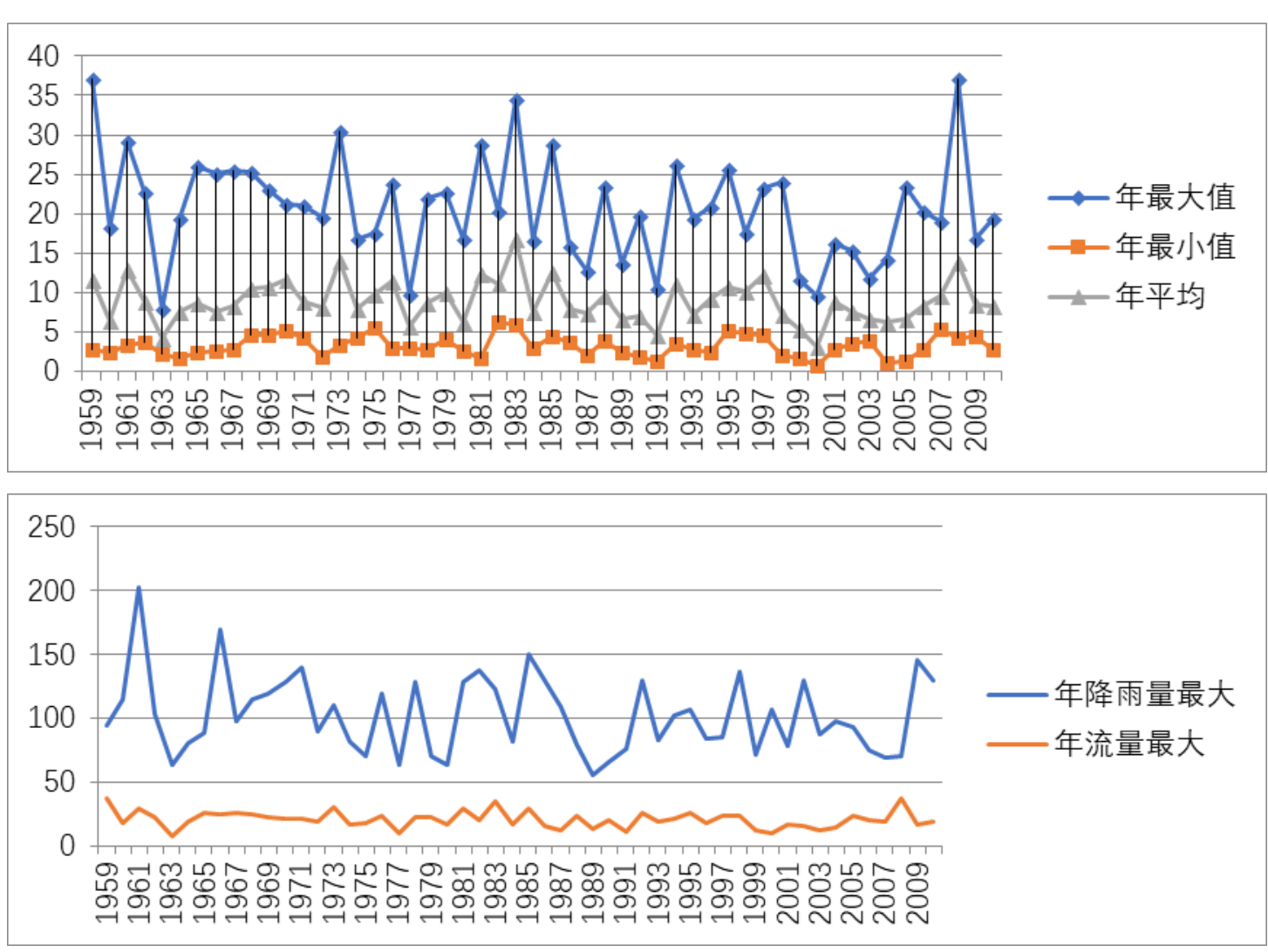

Figure 4.1959 2010 Annual Xiaohebu Hydrological Station Annual Rainfall \& Flow Statistics

Source: Xiaxiaohebu Hydrological Station

\subsection{Sponge City Construction Performance Model Simulation}

In this paper, two sets of representative rainfall data of Wuzhou Rainy Day (Rainstorm Day and Light Rain Day) are selected, and the rainfall data of two rain days are recorded in the three-season land use planning model, and six different scenarios are obtained. .

Table 1. 24-hour rainfall on two rainy days

\begin{tabular}{l|l|l}
\hline Time & Rainfall on March 30, 2014 & Rainfall on April 22, 2014 \\
\hline $0: 00$ & 7.1 & 0 \\
\hline $1: 00$ & 0 & 0 \\
\hline $2: 00$ & 2.8 & 0 \\
\hline $3: 00$ & 8.9 & 0 \\
\hline $4: 00$ & 3 & 0 \\
\hline $5: 00$ & 0 & 0 \\
\hline $6: 00$ & 10.3 & 0 \\
\hline $7: 00$ & 0 & 0.5 \\
\hline $8: 00$ & 0 & 0.6 \\
\hline $9: 00$ & 14 & 0.7 \\
\hline $10: 00$ & 16.5 & 0.8 \\
\hline $11: 00$ & 6.5 & 1.2 \\
\hline $12: 00$ & 3 & 2.3 \\
\hline $13: 00$ & 0 & 3.7 \\
\hline $14: 00$ & 9 & 5.2 \\
\hline $15: 00$ & 3 & 5.1 \\
\hline $16: 00$ & 10.5 & 3.4 \\
\hline $17: 00$ & 23.5 & 3.5 \\
\hline & &
\end{tabular}




\begin{tabular}{l|l|l}
\hline $18: 00$ & 0 & 1.1 \\
\hline $19: 00$ & 1.5 & 0.9 \\
\hline $20: 00$ & 0 & 0.4 \\
\hline $21: 00$ & 0 & 0.3 \\
\hline $22: 00$ & 0 & 0 \\
\hline $23: 00$ & 0 & 0 \\
\hline 汇总 & 119.6 & 29.7 \\
\hline
\end{tabular}

Source: Xiaxiaohebu Hydrological Station

Scene 1 is scenario 1 in the rainstorm day model simulation scenario on March 30, 2014, scenario 2 is scenario 1 on the April 22, 2014 rainy day model simulation scenario; scenario 3 is scenario 2 on March 30, 2014 rainstorm day Model simulation scenario, scenario 4 is scenario 2 simulation scenario on April 22, 2014, rainy day model; scenario 5 is scenario 3 on March 30, 2014 rainstorm day model simulation scenario, scenario 6 is scenario 3 in April 2014 The 22nd rainy day model simulates the scene.

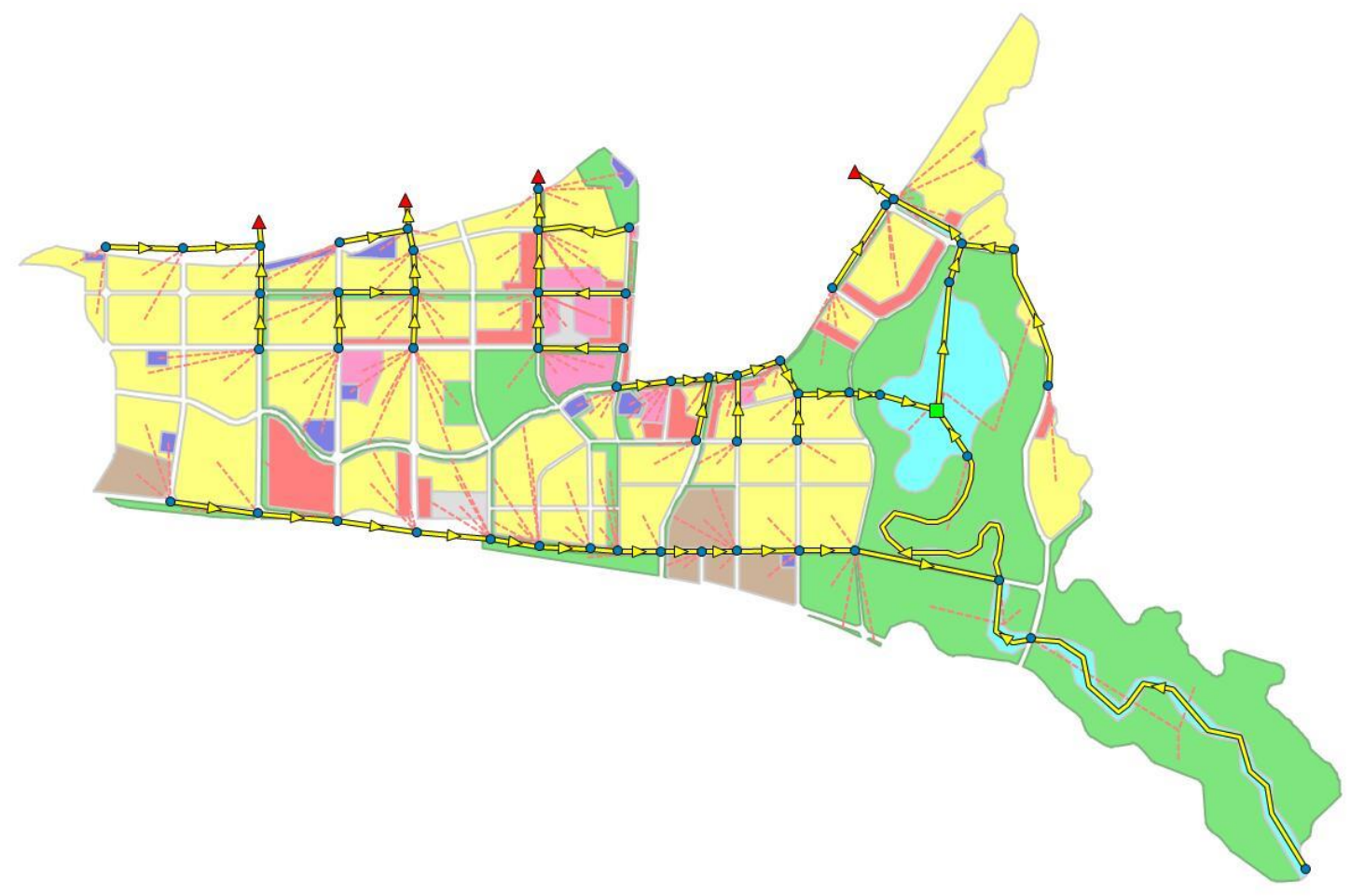

Figure 5. Scene 1, 2 initial state

Source: author paint 


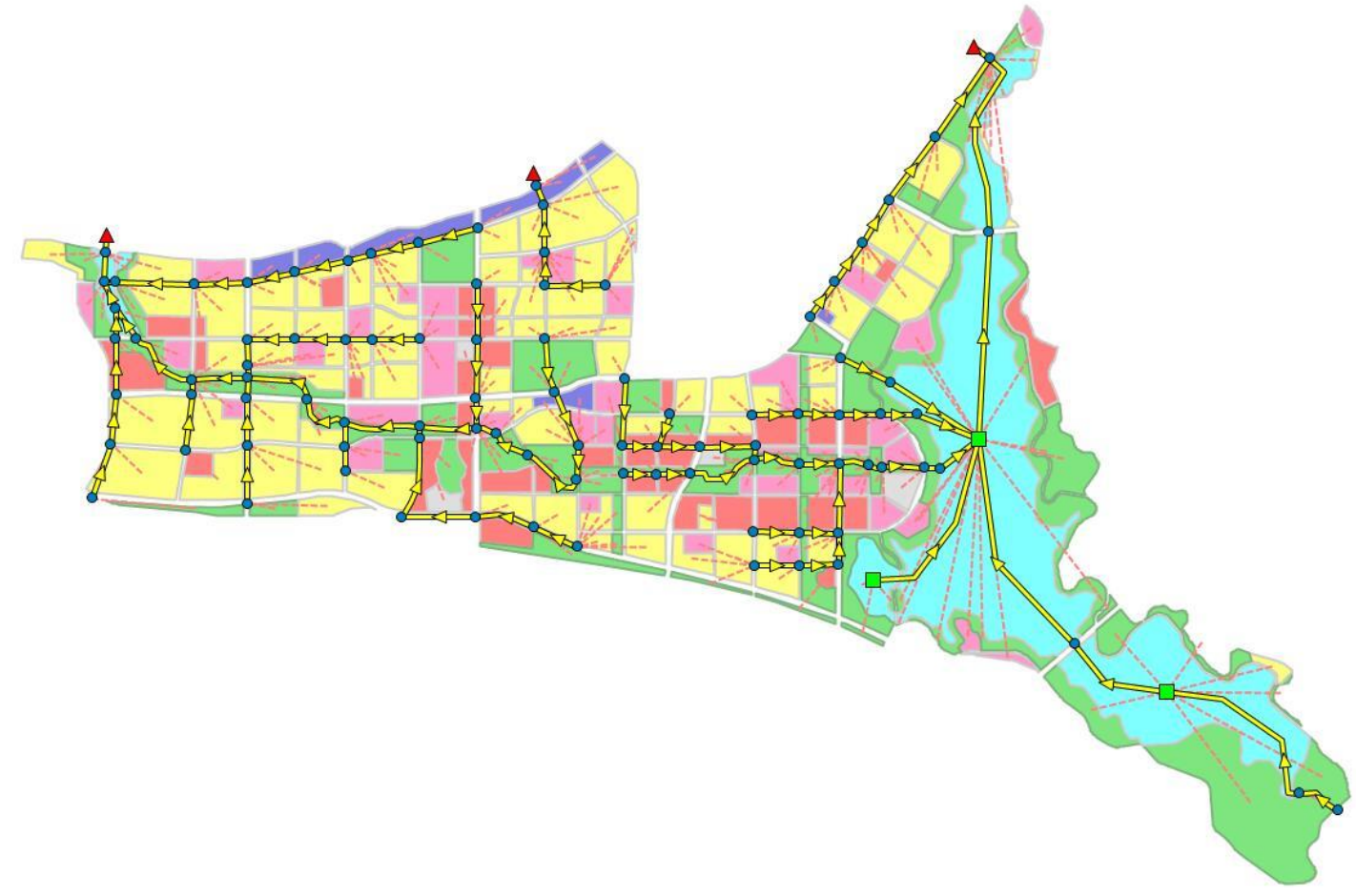

Figure 6. Scene 3, 4 initial state

Source: author paint

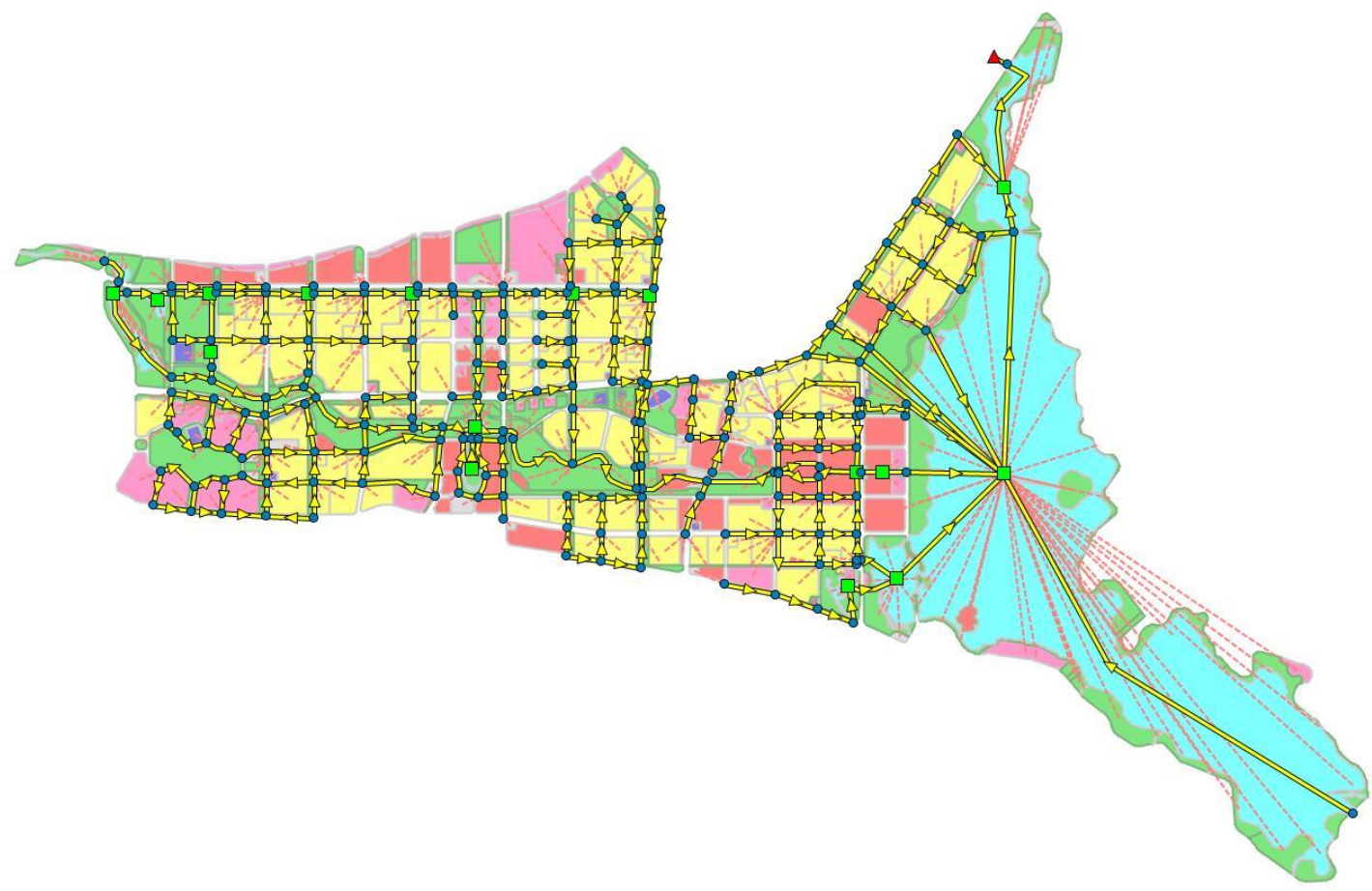

Figure 7. Scene 5, 6 initial state

Source: author paint

According to the performance evaluation indicators of the sponge city construction and research needs, the total green area, green space rate, total water area, water area percentage, total rainfall, total surface runoff, average water storage volume, maximum water storage volume, he number of rainstorm disaster points, the time of the most torrential rain disaster, the average torrential rain disaster time, the 
total time of the torrential rain disaster, the total flood amount of the torrential rain disaster, and the average flood amount of the torrential rain disaster point are comparative parameters.

Table 2. Statistics of different scenes

\begin{tabular}{|c|c|c|c|c|c|c|}
\hline \multirow{2}{*}{ Data } & \multicolumn{3}{|c|}{ Rainy day on March 30, 2014} & \multicolumn{3}{|c|}{ Rainy day on April 22, 2014} \\
\hline & scene 1 & scene 3 & scene 5 & scene 2 & scene 4 & scene 6 \\
\hline Total area of green space (hectare) & 561.50 & 370.44 & 326.80 & 561.50 & 370.44 & 326.80 \\
\hline Greenland rate $(\%)$ & 32.33 & 21.33 & 18.82 & 32.33 & 21.33 & 18.82 \\
\hline Total water area (hectare) & 121.18 & 335.96 & 490.06 & 121.18 & 335.96 & 490.06 \\
\hline Percentage of water area (\%) & 6.98 & 19.35 & 28.22 & 6.98 & 19.35 & 28.22 \\
\hline Total rainfall (million cubic meters) & 207.70 & 207.70 & 207.70 & 51.58 & 51.58 & 51.58 \\
\hline $\begin{array}{l}\text { Total surface runoff (million cubic } \\
\text { meters) }\end{array}$ & 149.58 & 127.88 & 110.01 & 27.52 & 25.16 & 21.91 \\
\hline $\begin{array}{l}\text { Average water storage volume } \\
\text { (million cubic meters) }\end{array}$ & 25.43 & 31.40 & 88.85 & 4.00 & 3.49 & 8.17 \\
\hline $\begin{array}{l}\text { Maximum water storage volume } \\
\text { (million cubic meters) }\end{array}$ & 69.15 & 101.58 & 276.94 & 7.35 & 6.21 & 22.49 \\
\hline $\begin{array}{l}\text { Number of rainstorm waterlogging } \\
\text { disaster points }\end{array}$ & 26.00 & 34.00 & 8.00 & 0.00 & 0.00 & 0.00 \\
\hline $\begin{array}{l}\text { The longest rainstorm } \\
\text { waterlogging time }(\mathrm{H})\end{array}$ & 11.69 & 11.85 & 4.18 & 0.00 & 0.00 & 0.00 \\
\hline $\begin{array}{l}\text { Average time of rainstorm } \\
\text { waterlogging disaster }(\mathrm{H})\end{array}$ & 5.97 & 4.41 & 3.74 & 0.00 & 0.00 & 0.00 \\
\hline $\begin{array}{l}\text { Total time of rainstorm } \\
\text { waterlogging disaster }(\mathrm{H})\end{array}$ & 155.20 & 149.80 & 29.91 & 0.00 & 0.00 & 0.00 \\
\hline $\begin{array}{l}\text { Total flood water of rainstorm } \\
\text { waterlogging }\end{array}$ & 65.68 & 22.61 & 18.35 & 0.00 & 0.00 & 0.00 \\
\hline $\begin{array}{l}\text { Average flood volume at the point } \\
\text { of rainstorm waterlogging (million } \\
\text { cubic meters) }\end{array}$ & 2.53 & 0.66 & 2.29 & 0.00 & 0.00 & 0.00 \\
\hline
\end{tabular}

Source: author paint

\subsection{Analysis of model simulation results}

(1) There are differences in the performance of sponge cities in different land use schemes.

(2) High green land ratio does not necessarily represent low surface runoff.

(3) The area of green land does not play a significant role in terms of prevention and control of rainstorm waterlogging.

(4) The size of the water area does not necessarily play a decisive role in the prevention and control of rainstorm waterlogging disasters.

(5) Water density plays an important role in the prevention and control of rainstorm waterlogging.

\section{Urban Land Use Optimization Strategy}

\subsection{Set Up an Ideal Model}

The research area of this paper is very large, there are many types of land use, and the geological conditions are also very complicated. Therefore, the surface runoff obtained, the time of flood disaster, the total amount of flood and other data of the model simulation are a result of many factors. It is difficult to determine which specific factor plays a decisive role in a certain result. 
A series of ideal models are established, that is, without considering the changes of topography, soil characteristics, groundwater conditions and erosion, only certain presets and changes are made for the variables to be studied, and the model output data is collated according to the research purpose, trying to figure out the relationship. According to the research needs, three sets of ideal models were established to study the pre-development and post-development changes of the site, the role of the green space system and the difference between the urban functional land.

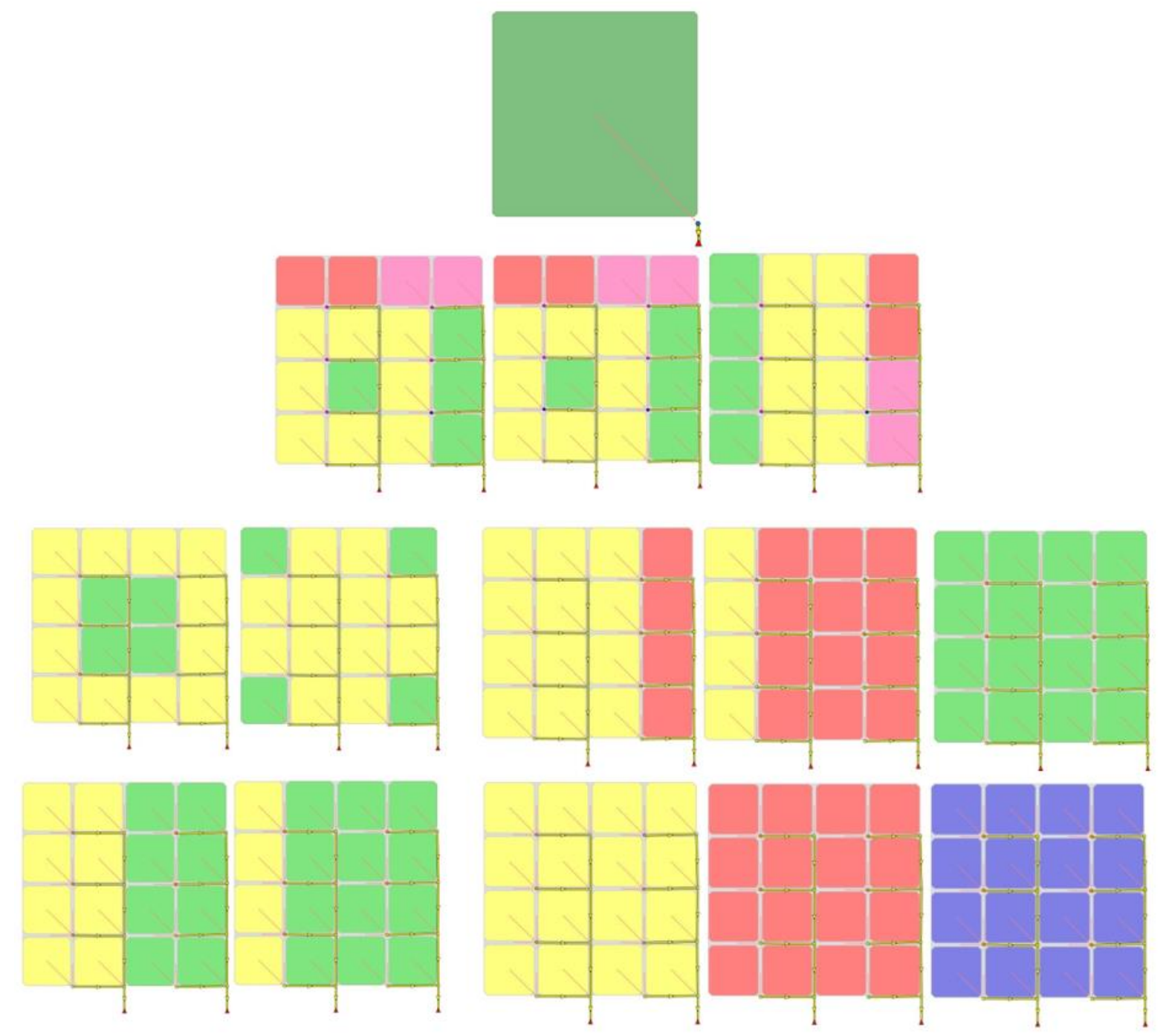

Figure 8. ideal model diagram

Source: author paint

\section{2. introduction of LID (low impact development) control technology}

Three LID technical measures of ecological detention unit, green roof and rainwater garden were introduced, and program 3 were introduced to establish model simulation to compare the effect of LID control measures on the construction performance of sponge city. 


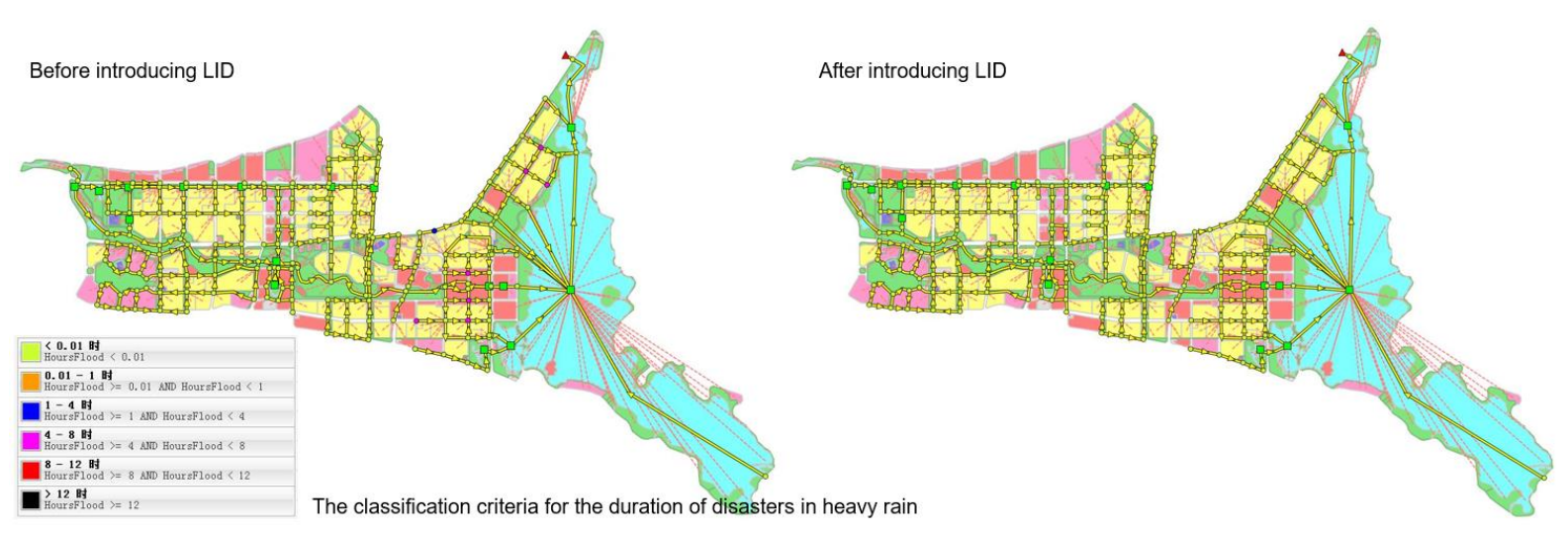

Figure 9. contrast map before and after the introduction of LID

Source: author paint

\subsection{Conclusion of model simulation and optimization strategy of improving urban}

\section{resilience}

\subsubsection{Model simulation conclusions}

(1) The LID control technical measures have no obvious influence on the evaporation amount and the infiltration amount under the conditions of constant temperature, wind speed and land structure.

(2) LID control technology measures can greatly control the total amount of surface runoff, and the effect is more obvious on light rain days.

(3) After the development and construction of the cities, the surface runoff will be increased due to the increase of the surface impervious rate. However, the surface runoff may be reduced to some extent or even lower than before the development if the LID control technology measures are introduced reasonably.

(4) The different proportion of urban functional land area will affect the surface runoff and urban rainstorm waterlogging disaster prevention and control, so the urban land area ratio has an impact on the construction performance of the sponge city.

(5) The functional land of the city has little effect on the evaporation due to the impervious rate, but it has an effect on the amount of infiltration, surface runoff and total flood, and with the increase of impervious rate, the amount of infiltration decreases and the surface runoff Increase, the total amount of floods increased.

(6) Green land is more conducive to increase the amount of infiltration, reduce the total surface runoff, and improve the ability to control surface runoff; however, in the prevention and control of flood disasters in heavy rain, the green rate does not play a significant role; In the green space system layout, centralized layout and decentralized layout have their own advantages and disadvantages.

\subsubsection{Optimization strategy of improving urban resilience}

The delayed water body can effectively improve the construction performance of the sponge city. The natural rivers and lakes or artificial excavation should be used as much as possible in the planning, but at the same time, the water density of the urban river network should be reasonably improved.

In the drainage planning, the rainwater should be discharged into the natural water body as soon as possible; when the funds are allowed and the planning is feasible, the rainwater pipe diameter should be increased as much as possible, and LID technical measures should be introduced; 
Urban planning does not necessarily pursue high green rate; in the layout of green space system, centralized layout and decentralized layout have their own advantages and disadvantages.

\section{Research Results and Applications}

\subsection{Theoretical Results}

There are mainly two theoretical results of this research: preliminary exploration of the performance evaluation method of sponge city construction based on land use planning perspective and empirical research, through the specific indicators of sponge city construction performance evaluation, and the application of sponge city construction performance evaluation model to form a set of methods to quantify the performance of sponge city construction, making the study of sponge city more rational; Based on the perspective of land use planning, this paper puts forward some strategies to improve urban resilience.

\subsection{Research applications}

This paper focuses on the urban planning stage of sponge city construction, focusing on the overall planning land use planning level in urban planning. Through the construction and operation of the simulation model, this paper try to propose a method that can quantify and evaluate the performance of sponge city construction, and analyze it. The optimal scheme is selected through this method. This paper puts forward some strategies to improve urban resilience from the perspective of land use planning, which can be used to optimize the scheme of the design stage of land use planning.

\section{References}

[1] Ministry of Housing and Urban-Rural Development. Technical Guide for Sponge City Construction Construction of Low Impact Development Rainwater System [M].2014.10

[2] Sponge City Construction Performance Evaluation and Assessment Method (Trial)

[3] Qiu Baoxing. The Connotation, Ways and Prospects of Sponge City (LID) [J]. Urban and Rural Construction, 2015, (2): 8-15.

[4] Xu Jie. Landscape Elasticity Evaluation and Simulation of Urban New District--Taking Canghai New District of Zhangzhou as an Example [D]. Tongji University, 2015.

[5] Wolfgang F. Geiger. Sponge City and Low Impact Development Technology - Vision and Tradition [J]. Landscape Design, 2015, 02: 10-21.

[6] Yu Kongjian, Li Dihua, Yuan Hong et al. Theory and Practice of "Sponge City" [J]. Urban Planning, 2015, 39(6): 26-36. DOI: 10.11819/cpr20150605a.

[7] Wang Hao. China's water resources issue and its scientific response, the report of the 13th Congress of the China Association for Science and Technology [EB/OL]. 2011-09-2 1.

[8] Chapman, C. and R. R. Horner (2010). "Performance assessment of a street-drainage bioretention system." Water Environment Research 82(2): 109-119

[9] Dreelin, E. A., L. Fowler and C. Ronald Carroll (2006). "A test of porous pavement effectiveness on clay soils during natural storm events." Water Research 40(4): 799-805.

[10] Jia, H., Y. Lu, S. L. Yu and Y. Chen (2012). "Planning of LID,ÄïMPs for urban runoff control: The case of Beijing Olympic Village." Separation and Purification Technology 84: 112-119. 